\title{
ВИБІР МЕТОДУ ОПТИМІЗАЦІЇ КРИТЕРІЇВ БАГАТОРІВНЕВОЇ СКЛАДНОЇ АГРЕГАТОВАНОЇ СИСТЕМИ
}

\begin{abstract}
Вступ
Основою побудови багаторівневої виробничої системи є знаходження екстремальних значень критеріїв оптимальності кожного рівня виробничої системи в технологічно обгрунтованих межах області варіювання фракторів. Такі обмеження суттево зменшують розміри області, в якій проводиться пошук оптимуму. Проте зменшення розмірів допустимої області не спрощує процедуру пошуку оптимуму, а навпаки, ускладнює їі, оскільки ряд методів оптимізації не можна використовувати при наявності обмежень. При цьому, може порушуватися основна умова, згідно з якою оптимум повинен досягатись в стаціонарній точці, що характеризується нульовим градієнтом.

Таким чином, клас досліджуваних методів повинен бути спрямований на знаходження умовного (як правило спостережуваного) екстремуму. Крім того, оскільки система є складною, часто, цільові фрункції є нелінійними і багатофакторними, це, в свою чергу, ускладнює вибір методу оптимізації.
\end{abstract}

\section{Постановка задачі}

У цілях обмеження розмірності задачі, розглянемо вибір методу оптимізації цільових функції для технологічного рівня гнучкої компютеризованої системи (ГКС) складання, яка має трьохрівневу структуру складального комплексу.

Першим рівнем означеної ієрархічної системи будемо вважати технологічну операцію, що виконуеться на певному складальному модулі. У якості критерія, на цьому рівні, доцільно прийняти машинний час виконання $i$-тої операції складального процесу.

На другому рівні можна розглядати кожний окремий складальний модуль, за характеристики якого приймемо циклову продуктивність (3) та коефіцієнт технічного використання (4).

Третій рівень ієрархічної системи ГКС складання будемо вважати сукупність параметрів, що впливають на собівартість продукції (в даному випадку складальних одиниць), прийнявши останню за критерій оптимізації останнього (вищого) рівня ієрархії.

Таким чином, кожний з рівнів може бути описаний кількома цільовими функціями $f_{i j}$, залежними від вектора параметрів $\overline{X_{i}}$ із області допустимих значень $D_{i}$ варійованих параметрів, де $i$ - номер рівня $(i=1,3) ; j$ - порядковий номер цільової функції на $i$-му рівні.

(c) М.М. Поліщук, Ю.О. Науменко, 2010 
До критеріїв оптимальності першого рівня належить задача оптимізації режимів технологічної операції складання методом стохастичного пошуку області сполучення складальних компонентів. До вказаних режимів належать наступні параметри $A$ - амплітуда зони пошуку сполучення, котра повинна перевищувати похибку взаємної орієнтації об'єктів складання; $S$ - крок, на який переміщуеться об'єкт, що приєднуеться до базового об'єкту складальної одиниці (вузла); $P$ - сила складання, що прикладена (наприклад, маніпулятором робота) до об'єкту, що приеднуеться.

Критерієм цільової функції, що об'єднуе вище вказані режими є машинний час операції - $T_{m}$, а сама функція отримана експериментальним методом:

$$
\begin{aligned}
& T_{M}=C_{0} P^{\alpha} A^{\beta} S^{\varepsilon} \rightarrow \min \\
& \text { при } P \in\{P\} ; A \in\{A\} ; S \in\{S\} \text {, }
\end{aligned}
$$

де $C_{0}$ - постійний коефіціент, який враховує вплив факторів, не відображених в функції; $\alpha, \beta, \varepsilon$ показники степеня, які характеризують вплив режимів корекції на час сполучення компонентів. Області допустимих значень $\{P\},\{A\},\{S\}$ обумовлюються технологічно обгрунтованими режимами складання.

Ще однією цільовою функцією першого рівня $е$ фрункція допоміжного часу (при умові рівномірності рухів):

$$
\begin{aligned}
& T_{b}=\sum_{k=1}^{g} \overline{L_{k}} / \overline{V_{k}} \rightarrow \min \\
& \text { при } L_{k} \in\{L\} ; V_{k} \in\{V\}
\end{aligned}
$$

де $\bar{L}$ - вектор відстаней на лімітуючій позиції; $\bar{V}$ - вектор швидкостей; $g$ - кількість допоміжних рухів, виконуваних на складальній позиції.

Цільвими функціями другого рівня $є$ циклова продуктивність та коефіціент технічного використання складальних модулів, відповідно:

$$
\begin{gathered}
Q_{u}=q /\left[k_{d i s}\left(T_{o n}^{\lim }+\sum_{k=1}^{q} T_{k}\right)+q T_{\min }\right] \rightarrow \max , \\
\eta_{T и}=1-\left\{T_{o n}^{\lim }\left(T_{o n}^{\lim } / \sum_{i} \sum_{j} B_{i j}-1\right) /\left(T_{\text {pes }}+T_{\text {обсл. }}\right)+1\right\}^{-1} \rightarrow \max \\
\text { при } T_{m} \in\{T\} ; T_{o n}^{\lim }=T_{m}+T_{b} ; k_{\text {dis }}=\text { Const } ; \\
T_{в} \in\{T\} ; B_{i j}=\text { Const } ; T_{\min }=\text { Const }
\end{gathered}
$$

Цільовими функціями третього рівня є собівартість складання деталей і фактична продуктивність, відповідно:

$$
\begin{gathered}
C=\left\{C_{u}(1+0,01 a)+\left(Ц / k_{c \mathcal{}} \Phi \eta_{\text {Ти }}\right)\left(T^{-1}+0,01 b\right)\right\} / m_{p} Q_{u} \rightarrow \min , \\
Q_{\phi}=m_{p} \eta_{T и} Q_{u} \rightarrow \max \\
\text { при } Q_{u} \in\{Q\} ;\left(C_{u}, Ц, k_{c \mathcal{}}, \Phi, T, a, b, m_{p}\right)=\text { Const }
\end{gathered}
$$


Не дивлячись на різний смисловий зміст цільвих функцій багаторівневої агрегатованої системи, всі вони з формальної точки зору зводяться до постановки однієї задачі: знайти значення змінних $x_{1}, x_{2}, \ldots, x_{n}$, які спричиняють максимум (мінімум) заданої скалярної функції $f\left(x_{1}, \ldots, x_{n}\right)$ при встановленій області допустимих значень $D$. Тобто виникае задача оптимізації скалярної функції, при заданих обмеженнях параметрів. Оскільки множина допустимих значень параметрів $\bar{x} \in X, X \neq \mathbb{R}^{n}$, то така задача оптимізації називається задачею умовної оптимізації.

\section{Синтез методу оптимізації}

Щоб віднести метод рішення задачі оптимізації до того, чи іншого типу задач, необхідно розглянути ряд обставин, які сприяють розв'язуваності скінченновимірних оптимізаційних задач:

- наявність тільки абсолютного екстремуму цільової функції;

- випуклість області визначення задачі і можливість вибрати значення $x_{j}$ серед всіх дійсних невід'емних чисел;

- гладкість функції $f(X)$, що полегшуе застосування апарату класичної математики для пошуку оптимальних рішень.

Якщо цільова фрункція $f(X)$ е лінійною фрункцією, то задача оптимізації вирішуеться методами лінійного програмування. В протилежному випадку слід використовувати методи нелінійного програмування.

Застосувавши вище описані умови, можна зробити висновок, що цільові функції системи є нелінійними. Отже, далі необхідно вирішувати задачу нелінійного програмування. Більшість нелінійних задач має особливості, які ускладнюють (а іноді роблять неможливим) дослідження загального характеру. В таких умовах великого значення набувають результати, які містять обгрунтовані і придатні для практичного застосування рекомендації.

Крім того, по вимогам до гладкості і наявності у цільової функції частинних похідних, методи оптимізації діляться на:

- прямі методи, які вимагають тільки обчислень цільової функції в точках наближення;

- методи першого порядку: вимагають обчислення перших частинних похідних фрунції;

- методи другого порядку: вимагають обчислення других частинних похідних, тобто гессіана цільової функції.

Серед класичних методів нелінійної умовної оптимізації можна виділити метод множників Лагранжа з використанням умови Каруша-КунаТаккера. В даному методі необхідною умовою знаходження екстремуму є наступний вираз:

$$
\left(\partial f / \partial x_{j}\right)_{x_{j}^{o}}-\sum_{i=1}^{m} \lambda_{i}^{o}\left(\partial g_{i} / \partial x_{i}\right)_{x_{j}^{o}} \leqslant 0,
$$


де $z=f\left(x_{1}, x_{2}, \ldots, x_{n}\right)$ - цільова фрункція, а $g_{i}\left(x_{1}, x_{2}, \ldots, x_{n}\right) \leqslant b_{i}(i=\overline{1, u})$ - функція обмежень.

Проте, застосувавши даний метод для знаходження екстремумів цільових функцій, описаної вище системи, можна зробити висновок, що він не $є$ ефрективним. Оскільки досліджувані функції не є неперервно диференційованими. Таким чином, для знаходження оптимуму фрункцій необхідно користуватися прямими методами, які не вимагають обчислення часткових похідних функції.

Слід зауважити, що метод оптимізації повинен приводити до кінцевого результату з найменшими витратами на обчислення і давати можливість отримати адекватну до робочого процесу інформацію про шукане рішення.

Взявши за основу описану постановку задачі оптимізації, можна звернутися до методів пошуку екстремуму в умовах невизначеності. Ці методи застосовуються, в основному для класу наступних задач:

- цільова фрункція не має аналітичного виразу;

- максимальне або мінімальне значення цільової функції і відповідні точки $X^{*}$ можуть бути отримані шляхом проведення ряду однорідних експериментів, число яких обмежене;

Звісно, застосування даних методів можливе і в тих випадках, коли вид залежності $z=f(X)$ відомий, але аналітичні методи рішення задачі по тим чи іншим причинам не вдаеться застосувати.

Одним з таких методів є метод Фібоначчі для пошуку екстремуму функції.

Реалізація данного методу пов'язана з використанням послідовності цілих чисел, відкритої італійським математиком Фібоначчі. Послідовність визначається формою:

$$
F_{1}=1, F_{2}=1, F_{n+1}=F_{n}+F_{n-1} n \in N
$$

Основне відношення, яке характеризує досліджуваний метод, має вигляд:

$$
L_{q-1}=L_{q}+L_{q+1}(q=\overline{2, N-1})
$$

Його аналіз зручно почати з конкретизації виразів $L_{q}(q=N, N-1, \ldots)$, звівши їх в таблицю 1.

Коефіціенти при $L_{N}$ i $\varepsilon$ в формулах таблиці утворюють послідовність чисел Фібоначчі. Використовуючи цю обставину, можна дати загальний запис виразу $L_{q}$, наведену в нижньому рядку таблиці, звідки слідуе $L_{N}=$ $\Phi_{N} L_{N}-\varepsilon \Phi_{N-2}$. Але $L_{1}$ є вихідним одиничним інтервалом невизначеності $\left(L_{1}=1\right)$, тому

$$
L_{N}=\left(1+\varepsilon \Phi_{N-2}\right) / \Phi_{N}
$$

Співвідношення (10) дозволяе оцінити ефективність методу чисел Фібоначчі, яка пов'язана з тим, що скорочення довжини чергового інтерва- 
лу $L_{q}$ вимагає проведення одного нового експеримента, тоді як в схемі методу дихотомії їх вимагалося б два.

Коеріцієнти при $L_{N}$ i $\varepsilon$

\begin{tabular}{|c|c|}
\hline$q$ & Вирази $L_{q}$ \\
\hline$N$ & $L_{N}=L_{N}$ \\
\hline$N-1$ & $L_{N-1}=2 L_{N-\varepsilon}$ \\
\hline$N-2$ & $L_{N-2}=3 L_{N-\varepsilon}$ \\
\hline$\ldots$ & $\ldots$ \\
\hline & $L_{q}=\Phi_{N-q+1} L_{N}-\Phi_{N-q-1} \varepsilon$ \\
\hline
\end{tabular}

Можливість реалізації методу пов'язана з вибором точки $x_{1}$. Із попереднього аналіза слідує $x_{1}=1-L_{2}$; але $L_{2}=\Phi_{N-1} L_{N}-\varepsilon \Phi_{N-3}$ або 3 врахуванням (10) $L_{2}=\Phi_{N-1}\left[\Phi_{N-1}+\varepsilon\left(\Phi_{N-1} \Phi_{N-2}-\Phi_{N} \Phi_{N-3}\right)\right]$. Звідси виходить, що зробити перший крок тут можна лиш тоді, коли назначено число $N$, тобто $x_{1}=x_{1}(N)$. Це $є$ недоліком, ускладнюючим для ряду випадків рішення задачі через неможливість змінити $N$ після початку експериментів.

\section{Висновки}

Вибір методу оптимізації строго залежить від правильної постановки задачі. Для розглянутої складної агрегатованої системи синтезовано метод чисел Фібоначчі. За допомогою данного методу можна знайти екстремуми всіх цільових фрункцій системи.

Здійснено оптимізацію режимів складання для умов приладобудівного виробництва.

\section{Література}

1. Дегтярев Ю. И. Методы оптимизации: Учеб. Пособие для вузов. - М.: Сов. Радио, 1980. - 272 с.

2. Справочник по оптимизационным задачам в АСУ / В. А. Бункин, Д. Колев, Б. Я. Курицкий, А. Н. Максименко, Ю. А. Сокуренко, А. Стоев. - Л.: Машиностроение, 1984. - 212 с.

3. Ямпольський Л. С., Полищук М. Н. Оптимизация процессов в гибких производственных системах. К.: Вид-во “Техніка”. - 1988 р.

Отримано 02.03.2010 p. 